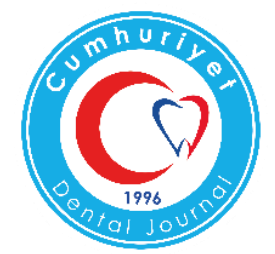

\title{
COMPARISON OF ANXIETY LEVELS AND PERCEPTIONS OF PATIENTS WITH INITIAL PERIODONTAL TREATMENT USING DIFFERENT ANESTHESIA AND INSTRUMENTS
}

\author{
Farklı Anestezi ve Enstrümanlarla Gerçekleştirilen Başlangıç Periodontal \\ Tedavinin Hastaların Anksiyete ve Algı Düzeylerine Etkilerinin Karşılaştırılması
}

Aysan LEKTEMUR ALPAN

\begin{abstract}
Makale Kodu/Article Code : 425767
Makale Gönderilme Tarihi $\quad$ :21.05.2018

Kabul Tarihi

: 27.11 .2018
\end{abstract}

\section{ABSTRACT}

Objectives: The aim of this study is to compare perception and anxiety levels of patients who are received different anesthesia and instruments prior to periodontal treatment.

Materials and Methods: The study performed in the Periodontology Department of Pamukkale University's Faculty of Dentistry (October 2017February 2018) and designed as randomized controlled clinical trial. 60 periodontitis patients were divided into 6 groups: 1-Local piezo, 2-Topical piezo, 3-Piezo, 4-Local hand instrument, 5-Topical hand instrument, 6- Hand instrument. Topical groups were received xylocaine spray; local groups were received jetocaine ampoule. Patients were asked to fill dental anxiety scale (DAS) scale before the treatment and $10^{\text {th }}$ day. The visual analogue scale (VAS) was filled out on the day of treatment, on the second day and on the $10^{\text {th }}$ day following treatment. Clinical measurements were taken on the treatment day and on the $30^{\text {th }}$ day.

Results: There was a significant decrease in clinical measurements in all groups. Local anesthesia groups revealed lower VAS pain values $(\mathrm{p}<0.05)$ compared to other groups on the day of the procedure. Topical anesthesia groups revealed lower VAS pain values as compared to the piezo and hand instrument groups, respectively $(\mathrm{p}>0.05)$. The ultrasonic groups exhibited lower DAS scores than the hand instrument groups ( $p>0.05)$.

Conclusion: Local anesthesia provided better patients cooperation and VAS pain scores, but did not yield good speech and chewing scores. Topical anesthesia and ultrasonic scaler usage may be more useful to patients with dental anxiety.

Key Words: anesthesia, DAS, dental anxiety, periodontitis, VAS

\section{ÖZ}

Amaç: $\mathrm{Bu}$ çalışmanın amacı, farklı anestezi teknikleri ve enstrümanlarla yapılan periodontal tedavi uygulanan hastaların alg1 ve anksiyete düzeylerini karşılaştırmaktır.

Gereç ve Yöntemler: Çalışma Pamukkale Üniversitesi Diş Hekimliği Fakültesi Periodontoloji Bölümü'nde (Ekim 2017- Şubat 2018) gerçekleştirildi ve randomize kontrollü klinik çalışma olarak tasarlanmıştır. 60 kronik periodontitis hastası 6 gruba ayrıldı: 1-Lokal piezo, 2-Topikal piezo, 3- Piezo, 4-Lokal el aleti, 5-Topikal el aleti, 6- El aleti. Topikal gruplara xylocain sprey, lokal gruplara ise jetokain ampul uyguland1. Hastalardan, tedavi öncesi ve tedavi sonrası 10. günde dental anksiyete skalasını (DAS) doldurmaları istendi. Görsel analog skala (VAS) tedavi günü, ikinci günü ve tedaviden sonraki 10. günde hastalar tarafından dolduruldu. Klinik ölçümler tedavi öncesi ve tedavi sonras1 30. günde alınd1.

Bulgular: Tüm gruplarda klinik ölçümlerde anlamlı bir iyileşme gözlendi. Lokal anestezi gruplarında, işlem gününde diğer gruplara göre daha düşük VAS ağrı değerleri $(p<0,05)$ ölçüldü. Topikal anestezi gruplarında ise piezo ve el aleti gruplarına göre daha düşük VAS ağrı değerleri saptandı $(\mathrm{p}>0,05)$. Ultrasonik gruplar, el aleti gruplarından daha düşük DAS skorları sergiledi ( $\mathrm{p}>0,05)$.

Sonuç: Lokal anestezi daha iyi hasta kooperasyonu ve daha az VAS ağrı skorları sağladı, ancak konuşma ve çiğneme skorlarını yükseltti. Topikal anestezi ve ultrasonik scaler ile gerçekleştirilen tedavi, dental anksiyete hastaları için daha yararlı olabilir.

Anahtar Kelimeler: Anestezi, DAS, dental anksiyete, periodontitis, VAS 


\section{INTRODUCTION}

Periodontitis is a disease caused by specific microorganisms and it causes periodontal ligament and alveolar bone loss by affecting the supporting tissues of teeth. ${ }^{1}$ It can usually be treated successfully with scaling, root planning (SRP) and periodontal surgery. Initial periodontal treatment includes subgingival and supragingival debridement and root surface planning. The SRP treatment of periodontitis involving mechanical treatment phase may be painful for the patient. ${ }^{2}$ Curettes, which are hand instruments for performing SRP, are widely used. However, even an operator with very good hand skills is unable to navigate the difficult root anatomy to obtain a biologically efficient clean root surface ${ }^{3,4}$ Furthermore, working with hand instruments can be tedious, laborious and time consuming. The excessive use of hand instruments may cause unintended root surface loss and postoperative root sensitivity ${ }^{5}, 6$ To improve the clinical and microbial results, sonic and ultrasonic scalers were developed to perform subgingival and supragingival debridement. Many studies that used these ultrasonic tools observed similar clinical outcomes to studies that used hand instruments ${ }^{7,8}$ Although ultrasonic scalers have many advantages, they have disadvantages as well, such as insufficient water cooling applied to pulpal and periodontal tissues $^{9}$, pathogenic bacterial aerosol ${ }^{10}$, and disturbing the patient with tooth contact. ${ }^{11}$

Pain is a feeling that develops from intense or harmful stimuli. It has been difficult to define pain, as it is a complex and subjective phenomenon. The widely used definition from the International Association for the Study of Pain states, "Pain is related with real or potential tissue damage and is an unpleasant sensory and affective with regards to this damage,". ${ }^{12}$

Dental anxiety are the emotions which develop alongside the important physiological stimulation. It can also develop with sensory stimulation and in response to procedures, dentistry objects, or dentistry procedure resources..$^{13}$ Anxiety surrounding a dentist and his treatment is considered to be one of the most common anxieties that people experience. Various scales and questionnaires have been established to determine the pain status and dental anxiety of the patients. Two of the most common of these scales the visual analogue scale (VAS) for pain measurement and the dental anxiety scale (DAS) developed by Corah for the measurement of dental anxiety. ${ }^{14}$ (Table 1)

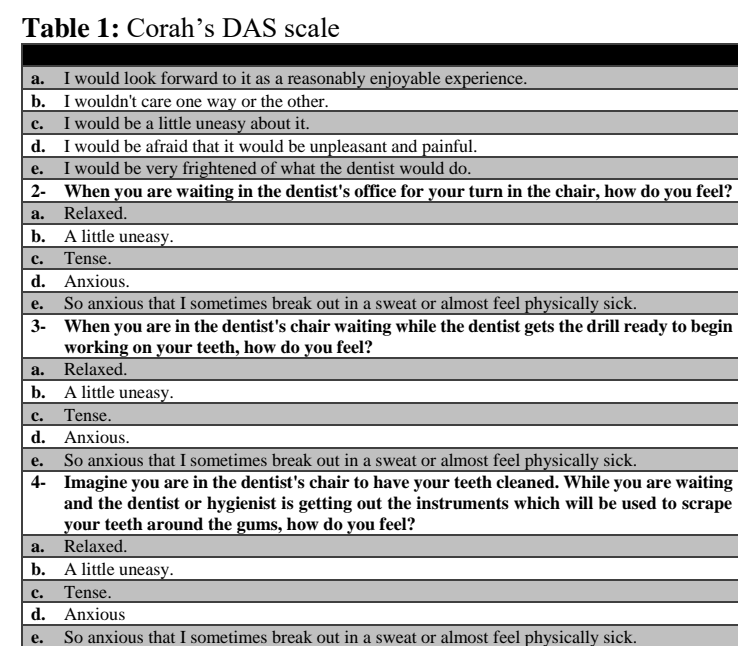

Local anesthesia provides reversible blockage of the nerves around the tissue. Anesthesia in dentistry is performed by using different techniques such as: 1-Conduction Anesthesia, 2-Infiltration Anesthesia and 3Topical or Surface Anesthesia. ${ }^{15}$ Although the use of local anesthesia provides a better neural blockage, the use of topical anesthetics for the patients who are anxious to injection may be an alternative approach.

The aim of our study was to investigate the effects of initial periodontal treatment which performed with different anesthetic methods with hand instruments and ultrasonic scalers on dental anxiety and the pain, chewing, speech perceptions perception levels of chronic periodontitis patients.

\section{MATERIAL AND METHODS}

The study received the approval of the Clinical Research Ethics Committee of Pamukkale University (number 2017/14) and was designed as a randomized controlled clinical trial. The 
population of our study were patients who applied for treatment in the Periodontology Department of Pamukkale University's Faculty of Dentistry between October 2017 and January 2018, and the study followed the principles of the Helsinki Declaration.

60 people, aged 26-55, came to the Pamukkale University Faculty of Dentistry Department of Periodontology with chronic periodontitis were involved in the study. The participants included chronic periodontitis patients who were healthy and at least in 4 of their teeth had a $4 \mathrm{~mm}$ probing depth; severe periodontitis patients, pregnant women, smokers, patients who use regular analgesics and inflammatory medications, women in their menstrual cycle and those who had anesthesia allergies were not involved.

After describing the treatments that would be implemented and obtaining written consent from the patients, they were asked to answer questions on the DAS scale. ${ }^{13}$ (Table 1) This scale involved 4 questions and 5 answers (a,b,c,d,e) that were scored 1,2,3,4 and 5, respectively, with sum of the scores achieving a total score (4 to 20 points). According to this scale, anxiety levels included mild anxiety (4 to 8 ), moderate anxiety ( 9 to 12 ), high anxiety (1314), and phobia (15 to 20$){ }^{16}$

The study groups were formed with complete randomization. The patients were randomly divided into 6 groups: 1 -local piezo $(\mathrm{n}=10), 2$-topical piezo $(\mathrm{n}=10), 3-$ piezo $(\mathrm{n}=10)$ 4-local hand instrument $(\mathrm{n}=10), 5$-topical hand instrument $(\mathrm{n}=10), 6$-hand instrument $(\mathrm{n}=10)$. (Figure 1)

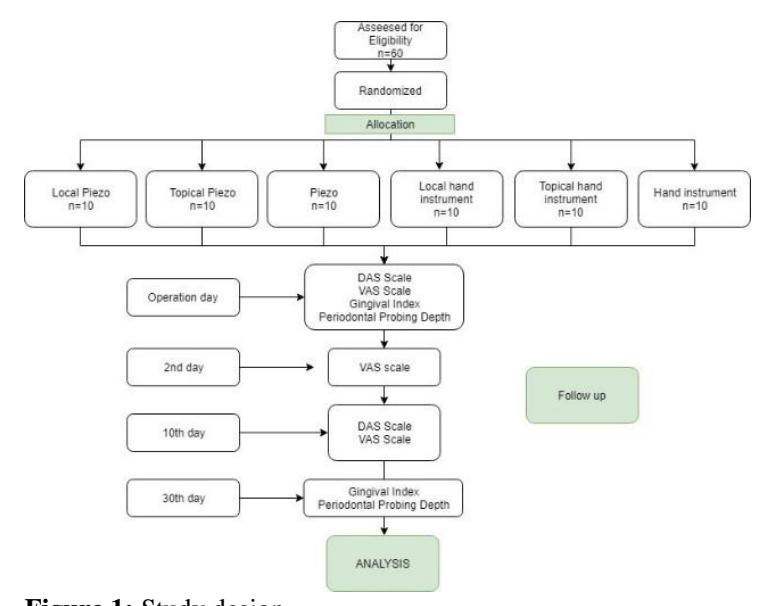

Figure 1: Study design

The patients in the piezo and hand instrument groups were not administered anesthesia, while the patients in the topical group were administered $10 \mathrm{mg}$ of lidocaine spray (xylocaine pump spray, AstraZeneca, Södertalje Sweden). The local groups received an anesthetic agent containing Lidocaine $\mathrm{HCl}$ $20 \mathrm{mg} / \mathrm{ml}$ and Epinephrine $\mathrm{HCl} 0.0125 \mathrm{mg} / \mathrm{ml}$ (Jetocaine ampoule, Adeka, Samsun, Turkey). The periodontal pocket depth and gingival index measurements were performed. ${ }^{17}$ Treatment of the ultrasonic groups involved a standard-unit-mounted piezoelectric scaler, and treatment in the hand instrument groups were performed with Gracey curettes and scalers for subgingival and supragingival debridement.

All patients filled out the VAS scale on the day of treatment, on the $2^{\text {nd }}$ day (the day after the operation) after treatment, and the 10th day after treatment, and they were asked to fill out the DAS scale again on the $10^{\text {th }}$ day. The VAS is a continuous scale comprised of a horizontal line $100 \mathrm{~mm}$ in length and describing pain intensity, the scale is most commonly anchored by "no pain, no trouble in chewing and speech" (score of 0 ) and "pain as bad as it could be" and "worst chewing and speech," (score of 100 [100-mm scale]). ${ }^{18}$ Clinical measurements were repeated at $30^{\text {th }}$ day.

\section{Statistical Analysis}

All of the data obtained from the study were evaluated by loading to SPSS data 22 (IBM Corp., NY, USA). Because parametric 
hypotheses were unfulfilled in the groups, nonparametric tests were applied. In the comparison of the binary groups, the Mann Whitney U test was used, and in the comparison of the one-way variance analysis, the Kruskal Wallis test was applied. For the evaluation of the initial and subsequent measurements of the groups, The Wilcoxon test was used. To the level of significance was taken as $\mathrm{p}<0.05$.

\section{RESULTS}

A total of 60 patients were enrolled in the study, with each group including 10 individuals. The ages and genders of the participants in each group were consistent.

When the initial probing depths and gingival indexes of the patients were compared with the 30th day probing depths and gingival indexes, there was a significant decrease in all groups $(\mathrm{p}<0.05)$, but there was no difference between the groups ( $p>0.05$ ). Different methods of initial periodontal treatment did not affect clinical outcomes during the day 30 . (Table 2)

Table 2: Initial and 30th day periodontal pocket depth and gingival index measurements of the groups

\begin{tabular}{lcccccc}
\hline & $\begin{array}{c}\text { Periodontal Pocket } \\
\text { Depth } \\
\text { (min-max)SD }\end{array}$ & $\begin{array}{c}\mathbf{P} \\
\text { value }\end{array}$ & \multicolumn{2}{c}{$\begin{array}{c}\text { Gingival Index } \\
\text { (min-max)SD }\end{array}$} & $\begin{array}{c}\mathbf{P} \\
\text { value }\end{array}$ \\
\cline { 2 - 7 } Local piezo & $\begin{array}{l}\text { initial } \\
30 \text { thth day }\end{array}$ & \multicolumn{4}{c}{ initial } & 30 th day \\
Topical piezo & $(4-5) 0,51$ & $(2-4) 0,47$ & $0.040^{*}$ & $(2-3) 0,48$ & $(0-1) 0,48$ & $0.005^{*}$ \\
Piezo & $(3-5) 0,81$ & $(2-4) 0.63$ & $0.023^{*}$ & $(2-3) 0.51$ & $(0-1) 0.42$ & $0.004^{*}$ \\
L Local hand instrument & $(3-6) 0.84$ & $(2-3) 0.51$ & $0.007^{*}$ & $(2-3) 0,48$ & $(0-2) 0,69$ & $0.006^{*}$ \\
Topical hand instrument & $(3-5) 0,67$ & $(2-3) 0.51$ & $0.006^{*}$ & $(2-3) 0.31$ & $(0-1) 0.52$ & $0.004^{*}$ \\
Hand instrument & $(3-6) 0,96$ & $(2-3) 0,51$ & $0.006^{*}$ & $(2-3) 0.42$ & $(0-1) 0.51$ & $0.004^{*}$ \\
\hline & $(3-5) 0,69$ & $(2-3) 0,51$ & $0.007^{*}$ & $(2-3) 0.31$ & $(0-1) 0.69$ & $0.004^{*}$ \\
\hline
\end{tabular}

When all VAS pain values of patients were compared, initial pain levels of the groups who received local anesthesia were significantly lower than in the other groups, but in these patients the pain levels on the $2^{\text {nd }}$ day increased significantly as compared to the first day levels. When we compared the initial pain levels in the topical anesthesia ultrasonic groups with the topical anesthesia hand instrument groups, we found the differences not to be statistically significant. Hand instrument groups (topical hand instrument and hand instrument) showed a significant decrease compared to the initial $(\mathrm{p}<0.05)$ (Figure 2).

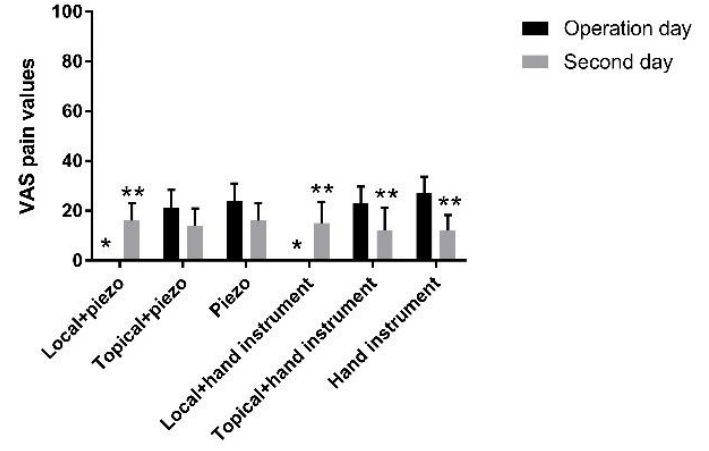

Figure 2: VAS pain values of patients. ${ }^{*} \mathrm{p}<0.05$ local+piezo and local hand instrument groups vs other groups at operation day, $* * \mathrm{p}<0.05$ operation day values vs second day values.

When VAS chewing values were compared, initial chewing values in groups that were received local anesthesia were found significantly higher than the other groups $(p<0.05)$. Although the initial chewing values in the ultrasonic groups were different from the hand instrument groups, they did not gain statistical significance ( $p>0.05)$ (Figure 3).

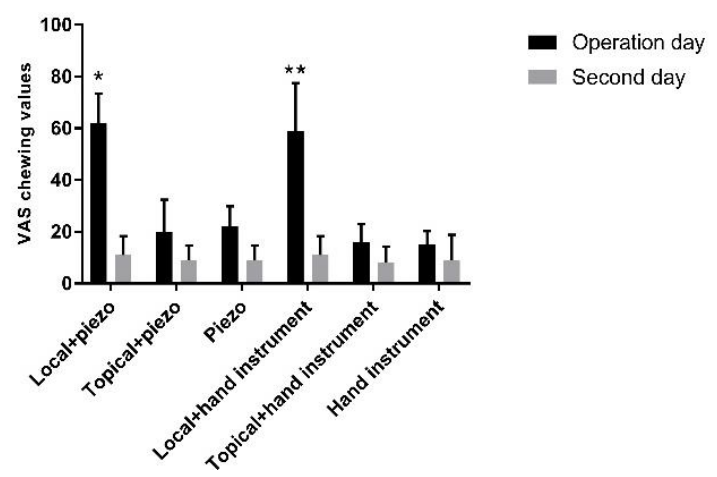

Figure 3: VAS chewing values of patients. ${ }^{*} \mathrm{p}<0.05,{ }^{*} \mathrm{p}<<0.05$ local+piezo and local+hand instrument vs other groups respectively.

When VAS speech values were compared, the initial local anesthesia groups values, apart from the hand instrument group, were significantly higher than the other groups $(p<0.05)$. On the $2^{\text {nd }}$ day there were no differences between the groups $(\mathrm{p}>0.05)$. (Figure 4) 


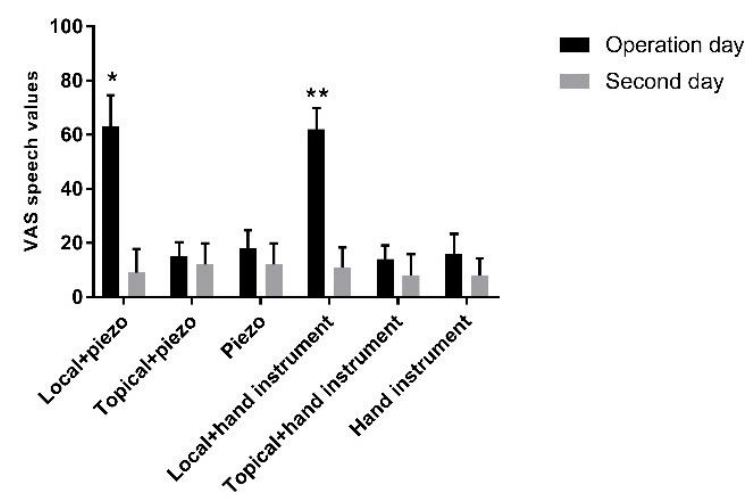

Figure 4: VAS speech values of patients. $* \mathrm{p}<0.05$, $* * \mathrm{p}<0.05$ local+piezo and local+hand instrument vs other groups respectively.

There was no difference between the groups regarding the initial DAS scale results (p>0.05). In the $10^{\text {th }}$ day measurement all groups showed a significant decrease compared to their initial values $(\mathrm{p}<0.05)$. (Table 3 ) Values in the ultrasonic groups are lower than hand instrument groups but not significant ( $\mathrm{p}>0.05$ ). Patients in this group gave lower values to question 4.

Table 3: Initial and 10th day DAS values of the groups.

\begin{tabular}{lccc}
\hline \multicolumn{1}{c}{ Groups } & $\begin{array}{c}\text { Initial DAS } \\
\text { values } \\
\text { Mean(SD) }\end{array}$ & $\begin{array}{c}\text { DAS values } \\
\text { 10th day } \\
\text { Mean(SD) }\end{array}$ & $\begin{array}{c}\text { P } \\
\text { value }\end{array}$ \\
\hline Local piezo & $14.20(1.181)$ & $6.10(2.079)$ & $0.005^{*}$ \\
Topical piezo & $13.30(1.947)$ & $7.20(1.751)$ & $0.005^{*}$ \\
Piezo & $12.70(2.869)$ & $7.40(2.221)$ & $0.008^{*}$ \\
Local hand instrument & $13.40(2.066)$ & $7.80(2.098)$ & $0.007^{*}$ \\
Topical hand instrument & $12.90(2.378)$ & $8.60(2.716)$ & $0.012^{*}$ \\
Hand instrument & $12.20(2.251)$ & $8.90(1.101)$ & $0.011^{*}$ \\
\hline
\end{tabular}

\section{DISCUSSION}

It was planned to measure the effect of initial periodontal treatment which includes supragingival subgingival debridement and is the first step of all periodontal treatments which can also be painful and to measure the effect of this treatment that can be performed in different forms on the dental anxiety in the study. According the results, local anesthesia provides less pain also topical anesthesia. The patients who received ultrasonic scaler treatment gave less anxiety scores especially the question number 4. In our study the patients with severe periodontitis were not involved because studies have indicated that the presence of severe inflammation increases the pain which will be occur in the treatment. ${ }^{19}$
Pain measurement can be difficult because it involves physical and psychological elements. Communication skills, person's psychological status, social and cultural background can change the severity of the pain from person to person. There are many scales available to measure pain and discomfort feeling. The VAS scale was used to measure post-operation pain, root sensitivity, and the pain during probing. ${ }^{19-21}$ In this study, the VAS scale which evaluates between $0-100$, was used. With this scale, both pain and chewing and speaking comfort are measured. In our study, the VAS scale was applied on the day of the operation and after 2 and 10 days. ${ }^{22}$

Guzeldemir et al. ${ }^{23}$ performed periodontal treatments with an ultrasonic device without using anesthesia in their study, and the average VAS scale was 19.91. In the study by Karadottir et al., the results of VAS in initial periodontal treatments, which were performed by two hygienists, varied between 15.1 and $10.8^{24}$ And in the study by Chung et al. ${ }^{2}$, the average scores were 22.3 and 19.5. Canakci and Canakci reported a score of 15.2. ${ }^{19}$ In our study, we found pain values of minimum 14 to a maximum of 24 in the ultrasonic groups outside of the local anesthetic groups and a minimum of 12 and a maximum of 27 in the hand instrument groups. Local anesthesia groups stated that they did not feel any pain upon first measurement, and their values were 0 . If local anesthesia had not been applied in the initial treatment of the groups, we came to the conclusion that the pain would increase, and the ultrasonic group and the hand instrument group would yield the same results. The first pain levels in ultrasonic groups were found to be higher than in the hand instrument groups. These differences may have arisen from the cooling processes while using the ultrasonic instruments and the impact of the piezo tip on cement and dentin.

In previous studies conducted, it was observed that $18 \%$ of patients had a fear of injections, and if this fear was of an average 
level, it would increase to $31 \% .{ }^{25}$ In these cases, topical anesthesia was used as an alternative and was found to be more successful than the placebo. ${ }^{26}$ In our study, topical anesthesia VAS values were lower than those of the nonanesthesia groups, but were insignificant. The VAS scale was also used to measure the chewing and speech perceptions. Even though the anesthesia groups were not able to speak or chew at first, this was due to the effects of the anesthesia. When the anesthesia wore off, there was no difference between the groups. Even though the local anesthesia groups showed less VAS values in terms of chewing and speech than the non-anesthesia groups, the differences between them and the anesthesia groups were statistically significant. This data is concordant with a recently published meta-analysis, which concluded that local anesthesia performs a decrease in the significantly deeper anesthesia and pain than in the topical anesthesia. ${ }^{27}$ In our study, we observed that patients felt pain even in the $2^{\text {nd }}$-day measurement. The reason for this pain may have been the sensitivity that arose from open dentinal tubules, which occurred with the removal after the ultrasonic device and hand instrument. This sensitivity can also make speaking and chewing difficult.

In this study, the Corah Dental Anxiety Scale was used to measure dental anxiety levels. DAS is a reliable and valid method for adults. ${ }^{14,28}$ In the evaluation of these scales, values between 4-6 were evaluated as low anxiety, while values of 10 and above were considered as high anxiety levels. In our study, the pre-treatment DAS values ranged from 12,20 to 14,20 . These values decreased to 6.10 8.90 after treatment. The knowledge and experience which were acquired previously by the patients about this treatment may have affected pre-treatment anxiety levels. After treatment, DAS values were seen as high in hand instrument groups. These results are taken from responses to the $4^{\text {th }}$ question, which reads, "Imagine you are in the dentist's chair to have your teeth cleaned. While you are waiting and the dentist or hygienist is getting out the instruments which will be used to scrape your teeth around the gums, how do you feel? Patients are afraid of the appearance of the curettage set and the instruments inside of it. In the studies, DAS scores show changes. These changes can depend on variables among people such as race, age, gender, psychological factors, and previous dental experiences.

\section{CONCLUSION}

Even though the treatment of chronic periodontitis patients occurs with anesthesia, they feel pain at a certain level when the anesthesia effect wears off. Topical anesthesia provided less benefit clinically than the local anesthesia. Dental anxiety levels have shown a decrease after treatment, but in ultrasonic groups anxiety decreased with regards to the hand instrument. More studies should be performed with more patients evaluating the levels of pain and anxiety. In addition, the patient's previous experiences should not to be ignored.

Acknowledgement: This study is a self funded study performed in Pamukkale University Department of Periodontolgy. The author stated that no conflict of interest abuout the study.

\section{REFERENCES}

1. Burt B. Position paper: epidemiology of periodontal diseases. J Periodontol 2005;76:1406-1419.

2. Chung DT, Bogle G, Bernardini M, Stephens D, Riggs ML, Egelberg JH. Pain experienced by patients during periodontal maintenance. J Periodontol 2003;74:12931301.

3. Sherman PR, Hutchens LH, Jr., Jewson LG. The effectiveness of subgingival scaling and root planing. II. Clinical responses related to residual calculus. J Periodontol 1990;61:9-15.

4. Sherman PR, Hutchens LH, Jr., Jewson LG, Moriarty JM, Greco GW, McFall WT, Jr. The effectiveness of subgingival scaling and root 
planning. I. Clinical detection of residual calculus. J Periodontol 1990;61:3-8.

5. Ritz L, Hefti AF, Rateitschak KH. An in vitro investigation on the loss of root substance in scaling with various instruments. J Clin Periodontol 1991;18:643-647.

6. Chabanski MB, Gillam DG, Bulman JS, Newman HN. Prevalence of cervical dentine sensitivity in a population of patients referred to a specialist Periodontology Department. J Clin Periodontol 1996;23:989-992.

7. Tunkel J, Heinecke A, Flemmig TF. A systematic review of efficacy of machinedriven and manual subgingival debridement in the treatment of chronic periodontitis. J Clin Periodontol 2002;29 Suppl 3:72-81; discussion 90-71.

8. Christgau M, Manner T, Beuer S, Hiller KA, Schmalz G. Periodontal healing after nonsurgical therapy with a modified sonic scaler: a controlled clinical trial. J Clin Periodontol 2006;33:749-758.

9. Nicoll BK, Peters RJ. Heat generation during ultrasonic instrumentation of dentin as affected by different irrigation methods. J Periodontol 1998;69:884-888.

10.Trenter SC, Walmsley AD. Ultrasonic dental scaler: associated hazards. J Clin Periodontol 2003;30:95-101.

11.Hoffman A, Marshall RI, Bartold PM. Use of the Vector scaling unit in supportive periodontal therapy: a subjective patient evaluation. J Clin Periodontol 2005;32:10891093.

12.Definitions" IAftSoPP. Pain is an unpleasant sensory and emotional experience associated with actual or potential tissue damage, or described in terms of such damage Derived from The need of a taxonomy. Pain 1979; 6:10.1016/0304-3959(1079)90046-90040.

13. Corah NL. Development of a dental anxiety scale. J Dent Res 1969;48:596.

14. Corah NL, Gale EN, Illig SJ. Assessment of a dental anxiety scale. J Am Dent Assoc 1978;97:816-819.
15. Boyce RA, Kirpalani T, Mohan N. Updates of Topical and Local Anesthesia Agents. Dent Clin North Am 2016;60:445-471.

16. Kirova DG, Atanasov DT, Lalabonova CK, Janevska S. Dental anxiety in adults in Bulgaria. Folia Med (Plovdiv) 2010;52:49-56.

17.Loe H, Silness J. Periodontal Disease in Pregnancy. I. Prevalence and Severity. Acta Odontol Scand 1963;21:533-551.

18.Akpinar A, Toker H, Lektemur Alpan A, Calisir M. Postoperative Discomfort After Nd: YAG laser and conventional frenectomy: comparison of both genders. Aust Dent J 2015. 19. Canakci V, Canakci CF. Pain levels in patients during periodontal probing and mechanical non-surgical therapy. Clin Oral Investig 2007;11:377-383.

20.Rollke L, Schacher B, Wohlfeil M, et al. Regenerative therapy of infrabony defects with or without systemic doxycycline. A randomized placebo-controlled trial. J Clin Periodontol 2012;39:448-456.

21.Muller N, Moene R, Cancela JA, Mombelli A. Subgingival air-polishing with erythritol during periodontal maintenance: randomized clinical trial of twelve months. J Clin Periodontol 2014;41:883-889.

22.Akpinar A, Toker H, Lektemur Alpan A, Calisir M. Postoperative Discomfort After Nd: YAG laser and conventional frenectomy: comparison of both genders. Aust Dent J 2015. 23. Guzeldemir E, Toygar HU, Cilasun U. Pain perception and anxiety during scaling in periodontally healthy subjects. J Periodontol 2008;79:2247-2255.

24. Karadottir H, Lenoir L, Barbierato B, et al. Pain experienced by patients during periodontal maintenance treatment. J Periodontol 2002;73:536-542.

25.Armfield JM, Heaton LJ. Management of fear and anxiety in the dental clinic: a review. Aust Dent J 2013;58:390-407; quiz 531.

26. Magnusson I, Jeffcoat MK, Donaldson D, Otterbom IL, Henriksson J. Quantification and analysis of pain in nonsurgical scaling and/or 
root planing. J Am Dent Assoc 2004;135:17471754.

27.Wambier LM, de Geus JL, Boing TF, et al. Intrapocket topical anesthetic versus injected anesthetic for pain control during scaling and root planing in adult patients: Systematic review and meta-analysis. J Am Dent Assoc 2017;148:814-824 e812.

28. Schuurs AH, Duivenvoorden HJ, Thoden van Velzen SK, Verhage F, Makkes PC, Eijman MA. Dimensionality of dental anxiety measurements. Community Dent Oral Epidemiol 1985;13:152-155.

\section{Corresponding Author}

Aysan LEKTEMUR ALPAN

Pamukkale University

Psikiyatri Hastanesi Arkası

(Eski Fizik Tedavi Binası)

Kınıklı Kampüsü

20070 Denizli/Turkey

Phone : +90 5053890608

Fax : +902582961763

E-mail : ysnlpn@gmail.com 